\title{
PENGELOLAAN SUMBERDAYA AIR PADA PERUSAHAAN DAERAH AIR MINUM KOTA YOGYAKARTA PASCA PUTUSAN MAHKAMAH KONSTITUSI NOMOR 85/PUU-XI/2013
}

\author{
M. Qori Oktohandoko \\ Pascasarjana Fakultas Hukum Universitas Muhammadiyah Yogyakarta, \\ Email : shein.dow@gmail.com
}

\begin{abstract}
ABSTRAK
Badan Usaha Milik Daerah (BUMD) memiliki peran penting dalam mewujudkan kemakmuran daerah dengan memberikan kontribusi terhadap Penerimaan Pendapatan Asli Daerah (PAD), baik dalam bentuk deviden atau pajak. Tantangan meningkatkan PAD salah satunya dapat dijawab dengan meningkatkan peran atau kontribusi BUMD. Putusan Mahkamah Konstitusi Nomor: 85/PUU-XI/2013 Tentang Pembatalan UU No. 7 Tahun 2004 Tentang Sumber Daya Air, telah memberikan peluang yang besar bagi pemerintah daerah untuk mengembangkan usahanya yang berbentuk BUMD, dengan pembatalan UUNo. 7 Tahun 2014 Tentang Sumber Daya Air, Pemerintah daerah sangat berpeluang mengembangkan BUMD di bidang air, yang saat ini di kelola oleh Perusahaan Daerah Air Minum (PDAM), dengan menggunakan metode penelitian hukum normatif, penelitian ini berupaya untuk mengaplikasikan Putusan Mahkamah Konstitusi Nomor: 85/PUU-XI/2013 Tentang Pembatalan UU No. 7 Tahun 2004 Tentang Sumber Daya Air, terhadap pelaksanaan dalam menjalankan Badan Usaha Milik Daerah, yang bergerak dalam usaha pengelolaan sumber daya air, sebagai wujud dari hak menguasai negara atas suatu yang menguasai hidup orang banyak.
\end{abstract}

Kata-kata kunci : Putusan, Mahkamah Konstitusi, Hak Menguasai Negara

\section{ABSTRACT}

Regional-Owned Enterprises (BUMD) have an important role in realizing regional prosperity by contributing to the Regional Revenue (PAD), either in the form of dividends or taxes. One of the challenges to increasing PAD can be answered by increasing the role or contribution of BUMD. Constitutional Court Decision Number: 85 / PUU-XI / 2013 concerning the cancellation of Law No. 7 of 2004 concerning Water Resources, has provided a great opportunity for regional governments to develop their businesses in the form of BUMD, with the cancellation of UU No. 7 of 2014 concerning Water Resources, the Regional Government is very likely to develop its BUMD in the water sector, which is currently managed by the Regional Water Company (PDAM), using normative legal research methods, this study seeks to apply the Constitutional Court Decision Number: 85 / PUU-XI / 2013 Regarding Cancellation of Law No. 7 of 2004 concerning Water Resources, for the implementation of running Regional-Owned Enterprises, which are engaged in 
the management of water resources, as a manifestation of the right to control the state of a person who controls the lives of many people.

Keywords: Decision of the Constitusional Court, The Right to Control the State

\section{PENDAHULUAN}

Konsep otonomi daerah, Pemerintah Daerah dituntut melakukan pengelolaan keuangan daerah secara efektif, efesien dan akuntabel. Pemerintah Daerah harus berusaha melakukan pengelolaan penerimaan daerah secara cermat, tepat dan hati-hati. Pemerintah Daerah harus menjamin bahwa semua potensi penerimaan telah terkumpul dan dicatat ke dalam sistem akuntansi pemerintahan daerah. Aspek utama dalam manajemen penerimaan daerah yang perlu mendapat perhatiaan serius adalah pengelolaan Pendapatan Asli Daerah (PAD). PAD harus menjadi bagian sumber keuangan terbesar bagi pelaksanaan otonomi daerah (Soleh\& Rocmansjah, 2010: 68) Hal ini menunjukkan berdasarkan Undang-Undang Nomor 32 Tahun 2004 Pasal 157 huruf a bahwa PAD merupakan tolak ukur terpenting bagi kemampuan daerah dalam menyelenggarakan dan mewujudkan otonomi daerah, sehingga PAD mencermikan kemandirian suatu daerah. PAD dapat berasal dari pajak daerah retribusi daerah, hasil pengelolaan kekayaan daerah yang dipisahkan, dan lain-lain PAD yang sah. PAD yang berasal dari hasil pengelolaan kekayaan daerah yang dipisahkan merupakan pendapatan yang berasal dari Perusahaan Daerah (PD) atau Badan Usaha Milik Daerah (BUMD).

BUMD memiliki peran dalam mewujudkan kemakmuran daerah dengan memberikan kontribusi terhadap Penerimaan PAD baik dalam bentuk deviden atau pajak. Tantangan meningkatkan PAD salah satunya dapat dijawab dengan meningkatkan peran/kontribusi BUMD. Secara makro, peranan PD atau BUMD terhadap perekonomian daerah dapat diukur melalui kontribusi nilai tambahnya terhadap Pendapatan Domestik Regional Bruto (PDRB) dan kemampuannya menyerap tenaga kerja (Purwadi, 2002: 3). Dalam perkembangan dunia usaha, BUMD dihadapkan tantangan yang berat. Sebagai wujud nyata dari investasi daerah, BUMD mau tidak mau akan menghadapi persaingan yang semakin tinggi dengan masuknya pasar global. Pilihannya adalah apakah BUMD tersebut harus tetap dengan kondisinya saat ini atau mengikuti persaingan itu dengan 
melakukan perubahan pada visi, misi, dan strategi bisnisnya. Melihat dari fungsinya, BUMD didirikan bertujuan untuk turut serta melaksanakan pembangunan daerah khususnya dan pembangunan ekonomi nasional umumnya untuk memenuhi kebutuhan rakyat menuju masyarakat yang adil dan makmur sebagaimana diatur dalam Undang-Undang Nomor 5 Tahun 1962 tentang Perusahaan Daerah Pasal 5 ayat (2). Namun, hingga saat ini tujuan tersebut belum secara nyata diwujudkan oleh PD atau BUMD. Kontribusi BUMD dalam menghasilkan PAD masih sangat minim.

BUMD secara ideal merupakan salah satu sumber penerimaan dari sebuah pemerintahan daerah. BUMD adalah sebuah perwujudan dari peran Pemerintah Daerah dalam pembangunan ekonomi daerah. Namun demikian dalam perkembangannya BUMD justru menjadi salah satu masalah keuangan daerah. Tidak hanya gagal menjadi sumber penerimaan, bahkan BUMD dapat membebani keuangan daerah. Harapan peranan ideal yang dimiliki BUMD tersebut terhambat dengan kondisi BUMD saat ini. Terdapat berbagai permasalahan yang dihadapi BUMD baik masalah internal berkaitan dengan manajemen perusahaan ataupun masalah eksternal berkaitan dengan tingkat persaingan yang sangat tinggi dan perubahan lingkungan usaha yang menimbulkan acaman bagi kelangsungan hidup perusahaan.

Berdasarkan penelitian yang dilakukan Purwadi (2002: 21-24). paling tidak terdapat 12 masalah umum yang dimiliki BUMD, yaitu : (1) campur tangan birokrasi tinggi, (2) kondisi mesin dan peralatan yang sudah ketinggalan, (3) lemahnya kemampuan permodalan, (4) banyaknya aset perusahaan yang tidak produktif (idle capacity), seperti tanah dan bangunan yang menyebabkan overhead relatif tinggi, (5) keterampilan pegawai pada umumnya masih rendah, (6) kurang jelasnya dasar hukum yang digunakan, tidak sesuai dengan kondisi saat ini, (7) marketing system yang dilakukan oleh BUMD relatif lemah, (8) adanya persaingan dari pihak swasta yang memproduksi barang sejenis, (9) kurang berfungsinya Badan Pengawas, (10) perusahaan-perusahaan daerah pada umumnya mempunyai posisi Debt to Equity Ratio yang tidak menguntungkan, sehingga resiko finansial dari perusahaan relatif tinggi, (11) beban keharusan untuk menyetor sebagian laba, dan (12) masih di pertahankannya BUMD yang merugi. Permasalahan yang lain dalam pengelolaan dan pengembangan BUMD adalah, belum adanya payung 
hukum yang memberikan arahan dan pedoman dalam pengelolaan sebuah badan usaha yang dimiliki oleh daerah, seperti layaknya BUMN yang sudah mempunyai payung hukum UU No 19 Tahun 2003. Pengaturan terkait dengan BUMD terutama dalam hal pendirian yang masih menggunakan dasar Perda dan UU No 5 Tahun 1962 Tentang Perusahaan Daerah sudah dirasa belum secara optimal menjawab tuntutan pengelolaan dan pengembangan BUMD (Muryanto, 2017)

Menurut Kunarjo relatif masih kecilnya penerimaan Bagian laba perusahaan daerah sebagai salah satu sumber PAD daerah, adalah bahwa kebanyakan usahanya relatif berskala menengah dan kecil, di samping banyak pula diantaranya yang belum diselenggarakan berdasarkan asas ekonomi perusahaan, namun relatif lebih banyak didasarkan atas pertimbangan pelayanan publik. Tambahan pula menurut Undang-Undang Nomor 5 Tahun 1962 Tentang Perusahaan daerah yang mendasarinya, terdapat rincian yang menetapkan bahwa penggunaan laba bersih perusahaan, setelah terlebih dulu dikurangi penyusutan (Muryanto, 2017).

Kompleksitas permasalahan pengelolaan dan pengembangan BUMD selain permasalahan di atas, belum adanya payung hokum yang memberikan arahan dan pedoman dalam pengelolaan sebuah badan usaha yang dimiliki oleh daerah, seperti layaknya BUMN yang sudah mempunyai payung hukum UU No. 19 Tahun 2003 Tentang Badan Usaha Milik Negara (BUMN). Pengaturan terkait dengan BUMD masih menggunakan dasar Perda dan UU No. 5 Tahun 1962 Tentang Perusahaan Daerah sudah dirasa belum mampu menjawab tuntutan pengembangan BUMD kearah profesionalisme. Selain permasalahan payung hukum tersebut, pengelompokan BUMD yang masih belum jelas menyebabkan distorsi terkait pengelolaan BUMD (Muryanto, 2017).

Menurut ketentuan Pasal 3 dalam Permendagri No 3 tahun 1998 tentang bentuk BUMD berupa perusahaan daerah dan BUMD berbentuk perseroan. Kedua kontruksi bentuk dan jenis BUMD tersebut diperlukan sebuah konsep atau model pengelolaan BUMD yang sesuai dengan karakeristik dan jenis BUMD itu sendiri. Dalam rangka pengelolaan BUMD secara profesional dan sesuai dengan prinsip- prinsip good corporate governance serta sesuai dengan tujuan didirikanya sebuah badan usaha yang berorentasi pada profit oriented dan tuntutan sebagai sebuah badan 
usaha yang didirikan untuk melayani kepentingan publik atau masyarakat, maka diperlukan sebuah model pengelolaan BUMD selaku entitas bisnis dan selaku entitas milik pemerintah daerah (Muryanto, 2017): 5).

Undang-Undang Nomor 7 Tahun 2004 Tentang Sumber Daya Air (UU SDA) disahkan menggantikan Undang-Undang Nomor 11 tahun 1974 Tentang Pengairan. UU SDA mengatur pengelolaan sumber daya air, khususnya oleh Negara. Negara menjamin hak setiap orang untuk mendapatkan air bagi kebutuhan pokok minimal sehari-hari guna memenuhi kehidupannya yang sehat, bersih, dan produktif, salah satunya adalah dalam penyediaan air minum sebagai salah satu kebutuhan dasar manusia. Dalam pengelolaan sumber daya air, untuk menyediakan air minum bagi rakyat, negara melakukan pengembangan sistem penyediaan air minum. Tanggung jawab dalam penyelenggaraan pengembangan sistem penyediaan air minum dimiliki pemerintah pusat dan pemerintah daerah. Pemerintah daerah dalam melaksanakan urusan pemerintah konkuren wajib yang berkaitan dengan pelayanan dasar, mempunyai kewenangan dalam pengembangan sistem penyediaan air minum. Ketentuan mengenai pengembangan sistem penyediaan air minum tersebut lebih lanjut diatur dalam peraturan pemerintah yaitu Peraturan Pemerintah Nomor 16 Tahun 2005 tentang Pengembangan Sistem Penyediaan Air Minum (Puspitasari\&Nindyaningrum, 2015: 14).

Dalam pelaksanaanya, pengembangan sistem penyediaan air minum sering mendapatkan protes dan kritik yaitu terkait dengan adanya isu privatisasi, komersialisasi dan swastanisasi air yang muncul di masyarakat dan aktivis air. Masyarakat khawatir dengan adanya eksplorisasi air yang dilakukan perusahaan akan menyebabkan kekeringan, sehingga mata air di daerah eksplorisasi tersebut akan mati. Indonesia sebagai negara yang menganut konsep negara kesejahteraan (welfare state), dimana pemerintah ikut campur dalam pengelolaan sumber daya air minum yang layak bagi seluruh rakyat Indonesia (Puspitasari\& Nindyaningrum, 2015: 47).

Permasalahan tersebut di atas bukan hanya karena permasalahan yang terjadi dalam pelaksanaan UU SDA saja, namun juga UU SDA masih banyak kekurangan dan belum sempurna. Komersialisasi dan swastanisasi dianggap muncul dari Pasal 40, Pasal 41, dan Pasal 45 UU No. 7 Tahun 2004 Tentang Sumber Daya Air. Ditambah UU No. 7 Tahun 2004 Tentang Sumber Daya Air dianggap kurang mengkomodir tanggung jawab Negara 
dalam sistem penyediaan air minum. Dari latar belakang itulah UU No. 7 Tahun 2004 Tentang Sumber Daya Air, dilakukan uji materi di Mahkamah Konstitusi.

Mahkamah Konstitusi (MK) pada tanggal 18 Februari 2015 melalui Putusan No. 85/PUU-XI/2013 telah membatalkan UU No. 7 Tahun 2004 Tentang Sumber Daya Air. Putusan ini merupakan puncak dari 2 (dua) putusan Mahkamah Konstitusi terdahulu mengenai Undang-Undang Sumber Daya Air tersebut. Dimana sebelumnya Mahkamah Konstitusi telah dua kali memutus uji materil atas UU SDA. Sebelumnya Mahkamah Konstitusi telah mengeluarkan Putusan Nomor 058-059-060-063/PUU-II/ 2004 dan Putusan Nomor. 008/PUU-III/2005 terkait uji materil UU SDA. Berulang kalinya UU SDA di uji materil menunjukan bahwa pada hakekatnya Undang-Undang tersebut mengandung masalah mendasar yang menyangkut syarat kosntitusionalitas (Conditionally Constitutional) pemberlakuan suatu undang-undang. Syarat konstitusional terkait dengan pengelolaan SDA oleh pemerintah yang harus dibangun diatas asas hukum hak menguasai negara sebagaimana ditegaskan oleh Pasal 33 UUD 1945 (Gunawan\&Wahyu, 2016: 115-116. Pasca Putusan MK No. 85/PUU-XI/2013 Tentang pembatalan UU No. 7 Tahun 2004 Tentang Sumber Daya Air, tentu memberikan dampak yang sangat besar bagi sistem penyediaan air, baik dalam sisi penyediaan sumber daya air, dan/atau tata kelola sumber daya air, begitu juga dalam dunia investasi yang bergerak dalam bidang sistem penyediaan air, oleh karena itu dalam penelitian ini akan dikaji terkait Strategi pengelolaan Sumber Daya Air pada Perusahaan Daerah Air Minum (PDAM) pasca Putusan MK No. 85/PUU-XI/2013 Tentang pembatalan UU No. 7 Tahun 2004 Tentang Sumber Daya Air.

\section{METODE PENELITIAN}

Artikel ini merupakan hasil dari penelitian hukum normatif dengan menggunakan studi kepustakaan yaitu penelitian hukum yang meletakkan hukum sebagai sebuah bangunan sistem norma. Oleh karena itu, penelitian ini menggunakan sumber bahan hukum baik primer dan sekunder maupun tersier. Penelitian ini mencoba mengkaji permasalahan hukum melalui tinjauan norma-norma hukum yang terdapat dalam peraturan perundang-undangan mengenai Pengelolaan Air pada PDAM Kota Yogyakarta, pasca Putusan MK No. 85/PUU-XI/2013 Tentang pembatalan 
UU No. 7 Tahun 2004 Tentang Sumber daya air. Kajian yang dilakukan ialah Pengelolaan oleh PDAM yang timbul akibat adanya Putusan MK No. 85/PUU-XI/2013 Tentang pembatalan UU No. 7 Tahun 2004 Tentang Sumber daya air (Fajar\&Achmad, 2013: 51). Digunakannya jenis penelitian hokum normatif, mengingat dari permasalahan yang ada akan dicari suatu penerapan terhadap adanya suatu sistem yang baru dalam suatu perundang-undangan.

Penelitian ini menjadikan bahan kepustakaan sebagai komponen utamanya, bahan hukum sekunder di dalam penelitian ini, antara lain, (i) berbagai buku yang mengemukakan teori-teori tentang negara kesejahteraan, (ii) Teori tentang penguasaan negara terhadap sumber daya alam (iii) berbagai buku tentang Badan Usaha Milik Daerah (BUMD), (iv) berbagai artikel, makalah, jurnal, dan hal-hal yang tercatata lainnya berkenan dengan pengelolaan sumber daya air. Bahan tersier terdiri antara lain (i) kamus hukum, (ii) kamus bahasa indonesia dan berbagai kamus lainnya yang relavan dengan kajian hukum dan negara kesejahteraan.

\section{HASIL DAN PEMBAHASAN}

1. Konsep Pengelolaan Sumber Daya Air Pasca Putusan MK No. 85/PUU-XI/2013 Tentang Pembatalan UU No. 7 Tahun 2004 Tentang Sumber Daya Air.

Pengembangan sistem penyediaan air minum memang merupakan tanggung jawab dari pemerintah pusat dan pemerintah daerah, namun penyelenggaraan dari sistem penyediaan air minum ini bisa dilakukan oleh BUMN dan BUMD, serta koperasi, badan usaha swasta, dan masyarakat juga ikut berperan dalam penyelenggaraan sistem penyediaan air minum, agar air minum dapat terpenuhi untuk seluruh masyarakat indonesia (Puspitasari\&Nindyaningrum, 2015: 51). Pada masa ini, Maria S.W Sumardjono mengemukakan kewenangan negara dalam hal penguasaan harus dibatasi oleh 2 (dua) hal yaitu dalam hal pengaturan dan pembatasan yang bersifat substansive, bahwa pertama, peraturan yang ada tidak boleh melanggar hak asasi manusia, sehingga seseorang yang melepas haknya harus mendapat perlindungan hukum dan penghargaan yang adil atas pengorbanan tersebut. Kedua, substansi dari peraturan tersebut harus untuk mencapai tujuan untuk sebesar-besarnya kemakmuran rakyat, kewenangan tersebut tidak dapat didelegasikan kepada pihak swasta. UU 
SDA sebagai payung hukum sistem penyediaan air minum rumah tangga tersebut tidak sejalan dengan 2 (dua) pembatasan yang dikemukakan oleh Maria S.W Sumardjono tersebut. Hal tersebut bisa kita lihat dari Pasal 40 ayat 4 UU No. 7 Tahun 2004 yang berbunyi sebagai berikut: koperasi, badan usaha swasta, dan masyarakat dapat berperan serta dalam penyelenggaraan pengembangan sistem penyediaan air minum.

UU SDA memperbolehkan penyelengaraan pengembangan sistem penyediaan air minum oleh swasta (Puspitasari\&Nindyaningrum, 2015: 52). Putusan Mahkamah Konstitusi Nomor: 85/PUU-XI/2013 menyatakan bahwa undang-undang SDA sudah tidak berlaku lagi dan/atau telah dibatalkan, sehingga dalam hal pengaturan sumber daya air kembali menggunakan undang-undang pengairan. Dan dalam Putusan Mahkamah Konstitusi Nomor 85/PUU-XI/2013 ada 6 (enam) pembatasan pengelolaan sumber daya air yaitu (Puspitasari\&Nindyaningrum, 2015: 53-54) :

a. Setiap pengusahaan atas air tidak boleh mengganggu, mengesampingkan, apalagi meniadakan hak rakyat atas air karena bumi, air dan kekayaan alam yang terkandung didalamnya selain harus dikuasai oleh negara juga peruntukannya adalah untuk sebesar-besarnya kemakmuran rakyat;

b. Negara harus memenuhi hak rakyat atas air. Sebagaimana dipertimbangkan di atas, akses terhadap air adalah salah satu hak asasi tersendiri maka Pasal 28 I ayat (4) UUD 1945 menentukan, "perlindungan, pemajuan, penegakan dan pemenuhan hak asasi manusia adalah tanggung jawab negara" terutama pemerintah."

c. Mengingat kelestarian lingkungan hidup, sebab sebagai salah satu hak asasi manusia, Pasal 28 H ayat (1) UUD 1945 menentukan: "setiap orang berhak hidup sejahtera lahir dan batin, bertempat tinggal, dan mendapatkan lingkungan hidup yang baik dan sehat serta berhak memperoleh pelayanan kesehatan."

d. Sebagai cabang produksi yang penting dan menguasai hajat hidup orang yang banyak yang harus dikuasai negara (vide Pasal 33 ayat (2) UUD 1945) dan air yang menurut Pasal 33 ayat (3) UUD 1945 harus dikuasai oleh negara dan dipergunakan untuk sebesar-besarnya untuk kemakmuran rakyat, maka pengawasan dan pengendalian oleh negara atas air sifatnya mutlak; 
e. Sebagai kelanjutan hak menguasai oleh negara dan karena air merupakan suatu yang sangat menguasai hidup orang banyak, maka perioritas utama yang diberikan pengusahaan atas air adalah Badan Usaha Milik Negara atau Badan Usaha Milik Daerah;

f. Apabila setelah semua pembatasan tersebut di atas sudah terpenuhi dan ternyata masih ada ketersediaan air, pemerintah di mungkinkan untuk memberikan izin kepada usaha swasta untuk melakukan pengusahaan atas air dengan syarat-syarat tertentu dan ketat.

Pada 6 enam point tersebut diatas, menyatakan bahwa negara harus hadir, dan membela serta melindungi hak-hak rakyatnya, dimana cabang-cabang produksi yang penting dan menguasai hajat hidup orang yang banyak yang harus dikuasai negara, makna dikuasai dan/atau menguasai bukan berarti negara harus memiliki, namun bisa dimaknai dengan cara negara ikut mengaturnya dengan bentuk pengawasan secara langsung dan/atau membentuk regulasi dan/atau peraturan perundangundangan untuk mengaturnya agar tidak melanggar hak-hak orang banyak, dan diperuntukan sebesar-besarnya untuk kemakuran rakyat. Dengan demikian konsep negara kesejahteraan dalam arti negara hukum pancasila dengan tujuan negara yang ingin dicapai melalui fungsi negara yang menjadi dasar keikutsertaan negara dalam pergaulan hidup masyarakat khususnya dalam bidang ekonomi menjadi jelas. Perwujudan tujuan negara sesuai dengan konsep negara kesejahteraan yang berlandaaskan pancasila hanya bisa tercapai kalau didukung dengan unsur kekuasaan negara di dalamnya. Tujuan negara yang terungkap demikian jelas dalam Undang-Undang Dasar (UUD) 1945 itu tentunya memerlukan suatu fungsi negara yang bukan hanya berfungsi sebagai pengatur atau pengendali semata, akan tetapi dibutuhkan pula fungsi negara sebagai penyedia kesejahteraan umum, pengusaha dan sebagai wasit yang adil dan fair dalam kegiatan perekonomian Negara (Puspitasari\&Nindyaningrum, 2015: 16-18).

Kemunculan usaha negara tersebut dalam bentuk perusahaan negara (state enterprises) dikarenakan adanya suatu anggapan yang sama, bahwa selalu ada sektor atau bidang yang dianggap penting bagi negara dan menguasai hajat hidup orang banyak serta dinilai vital atau strategis, sehingga hal tersebut tidak begitu saja dapat diserahkan pengelolaannya atau penyelenggaraannya kepada usaha swasta. Hal tersebut semakin 
diperjelas dengan gagalnya penerapan sistem ekonomi pasar melalui mekanisme pasar yang gagal (market failure) untuk mengendalikan perekonomian masyarakat, sehingga memerlukan keikutsertaan negara untuk mengatasinya (Puspitasari\&Nindyaningrum, 2015: 18-19). Oleh karena itu Peraturan perundang-undangan yang telah ada maupun yang akan dibentuk tidak boleh bertentangan dengan 6 (enam) prinsip dasar pembatasan pengelolaan sumber daya air yang di atur dalam Putusan Mahkamah Konstitusi Nomor 85/PUU-XI/2013.

Pasal 33 ayat (3) Undang-undang Dasar (UUD) 1945 menyatakan: Bumi dan air dan kekayaan alam yang terkandung didalmnya dikuasai oleh Negra dan dipergunakan untuk sebesar-besarnya kemakmuran rakyat. Menurut ketentuan Pasal 33 Ayat (3) UUD 1945 tersebut, negara bukanlah pemilik tetapi undang-undang dasar hanya memberikan hak penguasaan kepada negara untuk mengelola sesuai dengan tujuan yang telah digariskan oleh UUD 1945, yaitu dipergunakan untuk sebesar-besarnya kemakmuran rakyat" jadi, kedudukan negara dalam hal ini adalah wali amanat (trustes) dari kekayaan alam berupa air, antara lain, yang dianugrahkan tuhan kepada bangsa Indonesia. dengan demikian, UUD 1945 mengadopsi prinsip air sebagai barang publik (Chalid, 2019: 45).

Konstitusi Indonesia mengamanatkan kepada negara untuk menguasai sumber daya alam termasuk di dalamnya sumber daya air. Penguasaan oleh negara bukan berarti pemilikan oleh negara, rakyat Indonesia pemangku kedaulatan tertinggi merupakan pemilik sumber daya air, sehingga dengan kekuasaannya pemerintah harus melindungi dan memenuhi segala hak atas sumber daya air demi kesejahteraan rakyat indonesia. Hal ini sesuai dengan pendapat Mubyarto yang mengemukakan bahwa penguasaan oleh negara sebagaimana diamanatkan oleh UUD 1945, untuk menguasai cabang-cabang produksi tertentu yang menguasai hajat hidup orang banyak adalah bertujuan untuk meningkatkan kemakmuran rakyat secara maksimal. Hal ini sejalan dengan pandangan Soepomo yang mengemukakan bahwa penguasaan negara itu bisa diartikan mengatur dan/atau menyelenggarakan terutama memperbaiki dan mempertinggi produksi (Ilmar, 2012: 57). Hal tersebut juga diperkuat dengan Putusan Mahkamah Konstitusi Nomor. 001-021-022/PUU-I/2003 dengan memberikan frasa "dikuasai oleh negara" dala Pasal 33 UUD 1945. Putusan Mahkamah Konstitusi Nomor. 001-021-022/PUU-I/2003 Atas Permohonan 
Pengujian Uundang-undang Nomor 20 Tahun 2002 Tentang Ketenagalistrikan.menyebutkan bahwa:

Perkataan "dikuasai oleh negara" haruslah diartikan mencakup makna penguasaan oleh negara dalam arti luas yang bersumber dan berasal dari konsepsi kedaulatan rakyat Indonesia atas segala sumber kekayaan "bumi dan air dan kekayaan alam yang terkandung di dalamnya", termasuk pula di dalamnya pengertian kepemilikan publik oleh kolektivitas rakyat atas sumber-sumber kekayaan dimaksud. Rakyat secara kolektif itu dikonstruksikan oleh UUD 1945 memberikan mandat kepada negara untuk mengadakan kebijakan (belsaid) dan tindakan pengurusan (bestuursdaad), pengaturan (regelendaad), pengelolaan (beheersdaad) dan pengawasan (toezichthoudensdaad) untuk tujuan sebesar-besarnya.

Dalam Pasal 2 Ayat 1 UU No. 5 Tahun 1960 Tentang Peraturan Dasar Pokok Agraria (UUPA) juga menjelaskan bahwa hak menguasai negara terhadap bumi, air dan ruang angkasa bukan dalam artian memiliki, akan tetapi memberi kewenangan kepada negara sebagai organisasi kekuasaan dari bangsa Indonesia, untuk tingkatan tertinggi. Dalam Pasal 2 UU No. 5 Tahun 1960 Tentang Peraturan Dasar Pokok Agraria (UUPA) diatur bahwa hak menguassai dari negara memberi wewenang untuk:

a. Mengatur dan menyelenggarakan peruntukan, penggunaan, persediaan, dan pemeliharaan bumi, air dan ruang angkasa tersebut;

b. Menentukan dan mengatur hubungan-hubungan hukum antara orang-orang dengan bumi, air dan ruang angkasa;

c. Menentukan dan mengatur hubungan-hubungan hukum antara orang-orang dan perbuatan-perbuatan hukum yang mengenai bumi, air dan ruang angkasa.

Pada Perkara Nomor 85/PUU-XI/2013, Mahkamah Kosntitusi memutuskan, menyatakan bahwa UU No. 7 Tahun 2004 Tentang Sumber Daya Air tidak memiliki kekuatan hukum mengikat dan menyatakan UU No. 11 Tahun 1974 Tentang Pengairan berlaku kembali. UU No. 7 Tahun 2004 Tentang Sumber Daya Air dianggap sebagamana disebutkan dalam Alasan dalam Permohonan dalam Perkara Nomor: 85/PUU-XI/2013 yakni:

a. Mengandung muatan penguasaan dan monopoli sumber-sumber daya air yang bertentangan dengan prinsip-rinsip dikuasai oleh negara dan 
dipergunakan sebesar-besarnya untuk rakyat;

b. Mengandung muatan yang memposisikan bahwa penggunaan air adalah condong untuk kepentingan komersial;

c. Mengandung muatan yang memicu konflik horizontal;

d. Menghilangkan tanggung jawab negara dalam pemenuhan kebutuhan air; dan

e. Merupakan Undang-undang yang diskriminatif.

Mahkamah Konstitusi secara jelas dan tegas meletakkan titik tolak pertimbangan pengujian UU No. 7 Tahun 2004 Tentang Sumber Daya Air, pada Pasal 33 ayat (3) UUD 1945 yang menyatakan bahwa air adalah sebagai cabang produksi yang penting dan menguasai hajat hidup orang banyak yang harus dikuasai oleh negara dan air yang menurut Pasal 33 ayat (3) UUD 1945 harus dikuasia oleh negara dan dipergunakan untuk sebesar-besarnya kemakmuran rakyat, maka pengawasan dan pengendalian oleh negara atas air sifatnya mutlak sebagaiman disebutkan dalam Pertimbanagan hukum Mahkamah Konstitusi bagian 3.22 dalam Putusan Perkara Nomor 85/PUU-XI/2013.

Penguasaan sumber daya alam oleh negara, sebagaimana diatur dalam UUD 1945 tidak dapat dipisahkan dari peran negara yang bertujuan mewujudkan kemakmuran dan kesejahteraan rakyat sebesar-besarnya. Keterkaitan penguasaan oleh negara untuk kemakmuran rakyat, menurut Bagir Manan (1995:17) akan mewujudkan kewajiban negara dalam hal:

a. Segala bentuk pemanfaatan (bumi dan air) serta hasil yang didapat (kekayaan alam), harus secara nyata meningkatkan kemakmuran dan kesejahteraan masyarakat;

b. Melindungi dan menjamin segala hak-hak rakyat yang terdapat di dalam atau di atas bumi, air dan berbagai kekayaan alam tertentu yang dapat dihasilkan secara langsung atau dinikmati langsung oleh rakyat;

c. Mencegah segala tindakaan dari pihak manapun yang akan menyebabkan rakyat tidak mempunyai kesempatan atau akan kehilangan haknya dalam menikmati kekayaan alam.

Sebagai hak asasi manusia, maka pemenuhan hak atas air dilakukan dengan paradigma menghargai (to respect), melindungi (to protect) dan memenuhi (to fulfil). Paradigma demikian juga diadopsi dalam UUD 1945 sebagaimana yang disebutkan dalam ketentuan Pasal 28I ayat (4) UUD 1945, yang mengatur tentang tanggung jawab negara utamanya pemerintah 
dalam melindungi, memajukan, menegakkan dan memenuhi hak asasi manusia. Berdasrkan ketentuan ini pula, maka pemenuhan hak atas air sebagai bagian dari hak asasi manusia menjadi tanggung jawab negara khususnya pemerintah. Putusan Mahkamah Konstitusi Nomor: 85/PUU-XI/2013 Tentang Pembatalan UU No. 7 Tahun 2004 Tentang Sumber Daya Air, telah mengamanahkan dengan memberikan batasan pemenuhan hak atas air dalam Putusan Mahkamah Konstitusi Nomor. 85/PUU-XI/2013 Paragraf 3.19 s.d. Paragraf 3.24. sebagai berikut:

a. Setiap pengusahaan atas air tidak boleh mengganggu, mengesampingkan apalagi meniadakan hak rakyat atas air;

b. Negara harus memenuhi hak rakyat atas air;

c. Harus mengingat kelestarian lingkungan hidup sebagai salah satu hak asasi manusia;

d. Pengawasan dan pengendalian oleh negara atas air sifatnya mutlak;

e. Badan Usaha Milik Negara atau Badan Usaha Milik Daerah harus diberikan perioritas utama dalam hal penguasaan atas air;

f. Apabila setelah semua pembatasan tersebut di atas sudah terpenuhi dan ternyata masih ada ketersediaan air, pemerintah di mungkinkan untuk memberikan izin kepada usaha swasta untuk melakukan pengusahaan atas air dengan syarat-syarat tertentu dan ketat.

Berdasarkan amanah Putusan Mahkamah Konstitusi Nomor: 85/PUU-XI/2013 Tentang Pembatalan UU No. 7 Tahun 2004 Tentang Sumber Daya Air tersebut, terkhusus pada point 6, terlihat jelas akan Konsep Pengelolaan Sumber Daya Air Pasca Putusan Pasca MK No. 85/PUU-XI/2013 Tentang Pembatalan UU No. 7 Tahun 2004 Tentang Sumber Daya Air, telah bergeser dari yang awalnya pihak Swasta dapat dengan leluasa menguasai dan/atau mengelola sumber daya air, hal ini sesuai dengan Pasal 9 ayat 1 UU No. 7 Tahun 2004 Tentang Sumber daya Air, yang menyatakan, bahwa hak guna usaha air dapat diberikan kepada perseorangan atau badan usaha dengan izin dari pemerintah atau pemerintah daerah sesuai dengan kewenangannya. Selanjutnya Pasal 40 ayat 4 UU No. 7 Tahun 2004 Tentang Sumber Daya Air, menyatakan bahwa koperasi, badan usaha swasta, dan masyarakat dapat berperan serta dalam penyelenggaraan pengembangan sistem penyediaan air minum. Berubah menjadi pengelolaan sumber daya air di utamakan dikelola oleh negara dengan cara memberikan perioritas utama bagi Usaha Milik Negara atau 
Badan Usaha Milik Daerah untuk mengelola sumber daya air.

Sehingga hal tersebut memberikan peluang yang besar bagi Badan Usaha Milik Negara atau Badan Usaha Milik Daerah terkhusus Perusahaan Air Minum Daerah (PDAM) untuk mengembangkan usahanya, dengan kekuataan dan/atau dasar sekala perioritas utama untuk melakukan pengelolaan Sumber Daya Air dengan mendatangkan investor baik dari dalam negeri maupun investor luar negeri. Menurut Siti Anisa (14/12/2018), dalam hal mendatangkan investor pada bidang sumber daya air, bisa mengadopsi yang dilakukan oleh PT. Perusahaan Listrik Nasional (Persero) yang merupakan Badan Usaha Milik Negara. dimana wujud mendatangkan investornya mengundang pihak swasta untuk membangun usaha penyediaan tenaga listrik hal ini mendasarkan pada Pasal 11 ayat 1 UU No. 30 Tahun 2009 Tentang Ketenagalistrikan yang menyatakan:

Usaha penyediaan tenaga listrik untuk kepentingan umum sebagaimana dimaksud dalam Pasal 10 ayat (1) dilaksanakan oleh badan usaha milik negara, badan usaha milik daerah, badan usaha swasta, koprasi dan swadaya masyarakat yang berusaha di bidang penyediaan tenaga listrik.

Akhirnya hasilnya di jual kepada PT PLN, kemudian PT PLN menjual kepada masyarakat, hal ini bisa dilihat dari hubungan kerja antara PT. Paiton dengan PT. PLN (Persero) yang merupakan Badan Usaha Milik Negara. Dimana PT. Paiton penyedia tenaga listrik yang hasilnya dijual kepada PT. PLN (Persero), kemudian PT. PLN (Persero) menjual kepada Masyarakat, sehingga menguasaan tentang listrik masih ada pada pemerintah. Bahwa hal tersebut dilakukan sebagai wujud aplikasi terhadap Putusan Mahkamah Konstitusi Nomor. 001-021-022/PUU-I/2003. Hal ini sesuai dengan teori penguasaan negara menurut konstitusi, yang dikemukakan oleh Muhammad Hatta yang menjelaskan bahwa negara tidak harus secara langsung ikut mengelola dan/atau menyelenggarakan cabang produksi, akan tetapi hal itu dapat diserahkan kepada usaha koperasi atas swasta jika ada kelebihan ketersedian (Ilmar, 2012: 52-53), hal ini juga sejalan dengan putusan MK No. 85/PUU-XI/2013 Tentang Pembatalan UU No. 7 Tahun 2004 Tentang Sumber Daya Air, pada point ke-6 (enam) yang berbunyi " Apabila setelah semua pembatasan tersebut di atas sudah terpenuhi dan ternyata masih ada ketersediaan air, pemerintah di mungkinkan untuk memberikan izin kepada usaha swasta untuk melakukan 
pengusahaan atas air dengan syarat-syarat tertentu dan ketat". Namun negara tetap harus hadir dalam perwujutan pengawasan dan pembuatan peraturan-peraturan guna kelancaran jalannya ekonomi demi untuk menjamin terciptanya kesejahteraan rakyat. Oleh karena itu konsep pengelolaan sumber daya air harus tetap mengacu pada Pasal 33 ayat (3) UUD 1945, dimana sumber daya air yang merupakan sumber-sumber penting bagi masyarakat harus dikuasai oleh negara dan dipergunakan untuk sebesar-besarnya kemakmuran rakyat, maka pengawasan dan pengendalian oleh negara atas air sifatnya mutlak. Hal ini sebagai perwujutan negara kesejahteraan yang harus mengutamakan kepentingan seluruh rakyat indonesia dengan tugas dan fungsinya menyelenggarakan kepentingan umum.

2. Pengaturan dan Pengelolaan Sumber Daya Air di Perusahaan Daerah Air Minum (PDAM) Tirtamarta Kota Yogyakarta.

Selain bentuk-bentuk perusahaan negara dan daerah yang berbentuk PT. Persero dan Perum, maka di daerah terdapat juga bentuk perusahaan daerah (PD) sebagaimana yang diatur dalam Undang-undang No. 5 Tahun 1962 Tentang Perusahaan Daerah. Dengan dasar hukum tersebut, maka saat ini di berbagai daerah dijumpai bentuk Perusahaan Daerah Air Minum (Asikin\&Wihartana, 2016: 174). Dalam Pasal 2 Undang-undang No. 5 Tahun 1962 Tentang Perusahaan Daerah tersebut ditegaskan bahwa yang dimaksud dengan perusahaan daerah ialah semua perusahaan yang didirikan berdasarkan undang-undang ini yang modalnya untuk seluruhnya atau untuk sebagian merupakan kekayaan daerah yang dipisahkan, kecuali jika ditentukan lain dengan atau berdasarkan undang-undang (Asikin\&Wihartana, 2016: 175).

Menurut Pasal 4 Undang Undang No. 5 Tahun 1962 Tentang Perusahaan Daerah ditentukan bahwa: (1) Perusahaan daerah ialah didirikan dengan peraturan daerah atas kuasa undang-undang Undang-undang No. 5 Tahun 1962 Tentang Perusahaan Daerah, (2) perusahaan daerah termaksud pada ayat (1) adalah badan hukum yang kedudukannya sebagai badan hukum diperoleh dengan berlakunya peraturan daerah tersebut, (3) peraturan daerah termakasud pada ayat (1) mulai berlaku setelah mendapat pengesahan instansi atasan. Dari uraian di atas jelaslah bahwa perusahaan daerah dibentuk dengan peraturan daerah dan status badan hukum perusahaan daerah diperoleh dengan 
diundangkannya peraturan daerah yang mengatur pendirian perusahaan daerah tersebut. Dengan statusnya sebagai badan hukum, maka pertanggung jawaban pemegang saham dan direksi tentunya terbatas sesuai dengan tanggung jawab pada perseroan terbatas.

Sesuai dengan Pasal 5 UU No. 5 Tahun 1962 Tentang Perusahaan Daerah, maka tujuan Perusahaan daerah diatur, sebagai berikut: (1) perusahaan daerah adalah suatu kesatuan produksi yang bersifat memberi jasa, menyelenggarakan kemanfaatan umum, dan memupuk pendapatan, (2) tujuan perusahaan daerah ialah untuk turut serta melaksanakan pembangunan daerah khususnya dan pembangunan ekonomi nasional umumnya dalam rangka ekonomi terpimpin untuk memenuhi kebutuhan rakyat dengan mengutamakan industrialisasi dan ketentraman serta kesenangan kerja dalam perusahaan, menuju masyarakat yang adil dan makmur, (3) perusahaan daerah bergerak dalam lapangan yang sesuai dengan urusan rumah tangganya menurut peraturan-peraturan yang mengatur pokok-pokok pemerintah daerah, (4) cabang-cabang produksi yang penting bagi daerah dan yang menguasai hajat hidup orang banyak di daerah yang bersangkutan diusakahan oleh perusahaan daerah yang modalnya untuk seluruhnya merupakan kekayaan daerah yang terpisahkan.

3. Kepemilikan Modal PDAM Tirtamarta Kota Yogyakarta.

Perusahaan Daerah Air Minum (PDAM) Tirtamarta Kota Yogyakarta adalah sebagai wujud investasi dari pemerintah kota dalam bentuk perusahaan daerah, dengan dasar hukum PERDA No 14 Tahun 2012 Tentang Perusahaan Daerah Air Minum Tirtamarta Kota Yogyakarta, maksud dan tujaun didirikannya PDAM Kota Yogyakarta ialah sebagaimana disebutkan dalam Pasal 3 ayat (1) dan (2) PERDA No 14 Tahun 2012 Tentang Perusahaan Daerah Air Minum Tirtamarta Kota Yogyakarta yang berbunyi:

Ayat 1: PDAM dalam melakukan usahanya dengan maksud untuk memberikan pelayanan jasa, dan menyelenggarakan kemanfaatan umum serta menggali pendapatan daerah dengan motto pelayanan "Pelayanan Semakin Baik

Ayat 2: Tujuan PDAM adalah melaksanakan pembangunan daerah khususnya dan Pembangunan ekonomi nasional 
umumnya dalam rangka meningkatkan kesejahteraan masyarakat, khususnya dalam bidang air minum yang memenuhi syarat-sayarat kesehatan bagi masyarakat kota yogyakarta dan sekitarnya

PDAM sebagai salah satu penghasilan asli daerah (PAD) bagi pemerintah kota yogyakarta. yang bergerak pada penyediaan air minum dan/atau air bersih bagi masyarakat Kota yogyakarta, yang modal pendiriannya dari Pemerintah Kota yogyakarta, dan hingga pada tahun 2017, PDAM Tirtamarta Kota Yogyakarta telah mendapatkan penyertaan modal sejumlah Rp. 17,738.362.349,28,- (tujuh belas miliar Tujuh ratus tiga pulu delapan juta tiga ratus enam puluh dua ribu tiga ratus empat puluh sembilan rupiah) terdiri dari Rp. 15. 499.156.980,18,- (lima belas miliar empat ratus sembilan puluh sembilan juta seratus lima puluh enam ribu sembilan ratus delapa puluh rupiah) dari Pemerintah Kota Yogyakarta, dan Rp. 2. 239.205.369,10,- (dua miliar dua ratus tiga puluh sembilan juta dua ratus lima ribu tiga ratus enam puluh sembilan rupiah) dari Pemerintah Pusat.dan saat ini telah mengajukan dana penyertaan pada pemrintah kota yogyakarta, guna pengembangan usaha (Mujiya, 12/12/2018).

Sebagaimana uangkapan diatas, bahwa modal utama pendirian dari PDAM Tirtamarta Kota Yogyakarta, adalah dari pemerintah daerah, serta dari dana penyertaan dari pemerintah daerah dan pemerintah pusat, tentu hal ini telah sesuai dengan Pasal 5 ayat (1) dan (2) dan (3) PERDA No 14 Tahun 2012 Tentang Perusahaan Daerah Air Minum Tirtamarta Kota Yogyakarta yang berbunyi:

Ayat 1: Dalam rangka pencapaian cakupan pelayanan 8\% (delapan puluh per seratus), Pemerintah Daerah mengalokasikan anggaran melalui Anggaran Pendapatan dan Belanja Daerah (APBD) sebagai penyertaan modal untuk memperkuat struktur permodalan

Ayat 2 : Penabahan modal sebagaimana dimaksud pada ayat 1 bertujuan agar PDAM mampu mempercepat pencapaian cakupan pelayanan $80 \%$ (delapan puluh per seratus) dari jumlah penduduk perkotaan yang disesuaikan dengan rencana strategis bisnis (corporate plan). 
Ayat 3 : Semua alat likuid disimpan pada Bank Pemerintah atau Swasta yang sudah mendapatkan jaminan pemerintah".

Selain dari pada dasar hukum Pasal 5 ayat (1) dan (2) dan (3) PERDA No 14 Tahun 2012 Tentang Perusahaan Daerah Air Minum Tirtamarta Kota Yogyakarta tersebut, penyertaan modal yang diberikan oleh pemerintah Kota Yogyakarta kepada PDAM Tirtamarta Kota Yogyakarta juga mendasarkan pada Pasal 2 dan Pasal 4 ayat (1) dan (2) PERDA Kota Yogyakarta No. 6 Tahun 2015 Tentang Penyertaan Modal Pemerintah Kota Yogyakarta Kepada Badan Usaha Milik Daerah, yang menyatakan (Andarini, 10/12/2018):

Maksud penyertaan modal daerah adalah dalam rangka memperkuat struktural permodalan BUMD dan memperluas pelayanan kepada pelaku usaha mikro, kecil dan menengah dalam menyediakan permodalan dan jamina serta untuk meningkatkan pelayanan kepada masyarakat.

Pasal 4 ayat (1) dan (2) PERDA Kota Yogyakarta No. 6 Tahun 2015 Tentang Penyertaan Modal Pemerintah Kota Yogyakarta Kepada Badan Usaha Milik Daerah, yang menyatakan:

Ayat 1 : Ruang lingkup penyertaan modal daerah kepada BUMD terdiri atas: PD. BPR Bank Jogja dan PT Bank BPD DIY.

Ayat 2 : Pernyataan modal daerah pada BUMD bersumber dari Anggaran Pendapatan dan Belanja daerah.

Modal utama pendirian dari PDAM Tirtamarta Kota Yogyakarta, yang diberikan pemerintah daerah, dan dari dana penyertaan dari pemerintah daerah dan pemerintah pusat, juga sesuai, dengan Pasal 19 PP No. 54 Tahun 2017 Tentang Badan Usaha Milik Daerah, menyebutkan sumber modal badan usaha milik daerah adalah terdiri dari: (1) sumber modal BUMD terdiri atas, pernyertaan modal daerah, pinjaman, hibah, dan sumber modal lainnya, (2) penyertaan modal daerah sebagaimana dimaksud pada ayat 1 huruf a dapat bersumber dari: APBD; dan/atau konversi dari Pinjaman.

Pengajuan dana penyertaan yang saat ini di ajukan oleh PDAM Tirtamarta Kota Yogyakarta kepada pemerintah kota yogyakarta, juga telah sesuai denga Pasal 21 ayat 1 PP No. 54 Tahun 2017 Tentang Badan Usaha Milik Daerah yang menyebutkan: (1) penyertaan modal daerah dilakukan 
untuk pendirian BUMD, penambahan modal BUMD, dan pembelian saham pada perusahaan perseroan daerah lain. Sedangkan Pasal 23 PP No 54 Tahun 2017 Tentang Badan Usaha Milik Derah, menyebutkan: (1) penyertaan modal daerah dalam rangka penambahan modal BUMD dilakukan untuk pengembangan usaha, penguatan struktur permodalan, dan penugasan pemerintah daerah, (2) penyertaan modal daerah untuk penambahan modal BUMD sebagaimana dimaksud pada ayat 1 dilaksanakan setelah dilakukan analisa investasi oleh pemerintah daerah dan tersedianya bisnis BUMD. Sehingga dari uraian diatas, bisa dikatakan sumber modal yang digunakan oleh PDAM Tirtamarta Kota Yogyakarta, adalah telah sesuai dengan peraturan perundang-undangan yang berlaku yakni Pasal 19, 21 dan 23 PP No. 54 Tahun 2017 Tentang Badan Usaha Daerah, dan Pasal 5 PERDA No. 14 Tahun 2012 Tentang Perusahaan Daerah Air Minum Tirtamarta Kota Yogyakarta.

4. Bentuk Badan Hukum PDAM Tirtamarta Kota Yogyakarta.

PDAM Tirtamarta Kota Yogyakarta, adalah perusahaan milik daerah kota Yogyakarta atau bisa dikatakan Badan Usaha Milik Daerah, dalam bentuk Perusahaan daerah yang berkedudukan di daerah dan/atau kota Yogyakarta. Bahwa apa yang disampaikan Bapak Majiya Kabag Umum PDAM Tirtamarta Kota Yogyakarta, yang mengatakan PDAM Tirtamarta Kota Yogyakarta, adalah perusahaan milik daerah kota Yogyakarta atau bisa dikatakan Badan Usaha Milik Daerah, dalam bentuk Perusahaan daerah adalah telah sesuai dengan Pasal 2 Ayat 1 dan 2 PERDA No. 14 Tahun 2012 Tentang Perusahaan Daerah Air Minum Tirtamarta Kota Yogyakarta, yang berbunyi sebegai berikut:

Ayat 1: PDAM merupakan Badan Usaha Milik Daerah yang berbentuk Perusahaan Daerah;

Ayat 2: PDAM berkedudukan di Daerah"

Selain diatur dalam PERDA No. 14 Tahun 2012 Tentang Perusahaan Daerah Air Minum Tirtamarta Kota Yogyakarta, bentuk badan hukum BUMD juga diatur pada Pasal 114 PP No. 54 Tahun 2017 tentang Badan Usaha Milik Daerah yang menyatakan senagai berikut:

a. BUMD dapat melakukan perubahan bentuk hukum;

b. Perubahan bentuk hukum sebagaimana dimaksud pada ayat 1 dalam rangka mencapai tujuan BUMD dan Restrukturisasi; 
c. Perubahan bentuk hukum BUMD sebagaimana dimaksud pada ayat 1 terdiri atas:

1) Perubahan bentuk hukum perusahaan umum daerah menjadi perusahaan perseroan daerah; dan

2) Perubahan bentuk hukum perusahaan perseroan daerah menjadi perusahaan umum daerah;

d. Perubahan bentuk hukum BUMD sebagaimana dimaksud pada ayat (1) ditetapkan dengan PERDA;

e. Ketentuan lebih lanjut mengenai perubahan bentuk BUMD diatur dalam Peraturan mentri.

5. Pengangkatan Direksi PDAM Tirtamarta Kota Yogyakarta.

Secara umum, cara pengangkatan Direksi PDAM Tirtamarta Kota Yogyakarta, diangkat oleh Walikota Yogyakarta, berdasarkan usulan dari pengawas, dan proses selama ini yang berjalan adalah, adanya edaran dan/atau pengumuman lowongan jabatan dengan syarat-syarat tertentu, yang di tujukan kepada Walikota Yogyakarta, dan setelah melalui seleksi, maka nama yang lolos akan di bawa tim pengawas untuk di ajukan kepada Walikota Yogyakarta, dan keputusan terakhir ada pada Walikota Yogyakarta (Mujiya, 12/12/2018). Bahwa secara umum proses pengangkatan Direksi PDAM Tirtamarta Kota Yogyakarta sudah sesuai dengan peraturan yang ada pada kota Yogyakarta, Yakni Pasal 9 PERDA No. 14 Tahun 2012 Tentang Perusahaan Daerah Air Minum Tirtamarta Kota Yogyakarta, dalam pasal tersebut mengatakan:

Pasal 9 PERDA No. 14 Tahun 2012 Tentang Perusahaan Daerah Air Minum Tirtamarta Kota Yogyakarta: (1) Direksi diangkat oleh Walikota atas usus Dewan Pengawas, (2) batas Usia Direksi yang berasal dari luar PDAM pada saat diangkat pertama kali berumur paling tinggi 50 (lima puluh) tahun, (3) batas usia Direksi yang berasal dari PDAM pada saat diangkat pertama kali berumur paling tinggi 55 (lima puluh lima) tahun, (4) jabatan Direksi berakhir pada saat yang bersangkutan berumur paling tinggi 60 (enam puluh) tahun.

6. Bidang Usaha PDAM Tirtamarta Kota Yogyakarta.

PDAM Tirtamarta Kota Yagyakarta adalah perusahaan daerah, yang bergerak pada pengolahan air minum dan/atau air bersih yang diperuntukan dan/atau disalurkan untuk masyarakat Yogyakarta. Bahwa 
dalam melakukan pengelolaa sumber daya air PDAM Tirtamarta Kota Yogyakarta juga berpedoman pada prinsip-prinsip fungsi pengelolaan air yakni: fungsi social, fungsi ekonomi, dan fungsi pengelolaan lingkungan hidup.

Selain menjalankan fungsi ekonomi sebagai perwujudan perusahaan daerah yang berfungsi sebagai penghasilan asli (PAD), PDAM Tirtamarta Kota Yogyakarta juga menerapkan fungsi sosial yang berbentuk sosial umum dan sosial khusus, seperti pemberian tarif khusus bagi tempat-tempat ibadah dengan harga yang relatif murah, selain itu juga PDAM Tirtamarta Kota Yogyakarta menjalankan fungsi pengelolaan lingkungan hidup yang diwujdkan dengan pemberian uang santunan didaerah lokasi sumber air dan/atau sumur-sumur bor milik PDAM Tirtamarta kota Yogyakarta, untuk konserfasi alam.

Isu kekurangan penyediaan air untuk masyarakat kota yogyakarta telah ada sejak 10 (sepuluh) tahun yang lalu, sehingga untuk memenuhi kebutuahan air masyarakat kota Yogyakarta, pada bulan November 2017, PDAM Tirtamarta Kota Yogyakarta bekerjasama dan/atau membeli air dari SPAM Regional Kartamantul yang dikelola oleh Pemerintah Provinsi D.I. Yogyakarta, dengan sistem kerjasama, dimana SPAM Regional Kartamantul menyediakan air minum dan/atau air bersih, yang kemudian disalurkan dan/atau dijual pada PDAM Tirtamarta Kota Yogyakarta, dan PDAM Tirtamarta Kota Yogyakarta menjual kepada masyarakat Yogyakarta (Mujiya, 12/12/2018). Bahwa bidang usaha pengelohan dan penyediaan air minum dan/atau air bersih yang dijalani oleh PDAM Tirtamarta Kota yogyakarta, adalah memang bidang usaha yang mendasari di bentuknya PDAM Tirtamarta Kota Yogyakarta, dan bidang usaha pengelolaan dan/atau penyediaan air minum dan/atau air bersih kepada masyarakat yogyakarta ini telah diataur dalam Pasal 4 Ayat 1 PERDA No. 14 Tahun 2012 Tentang Perusahaan Daerah Air Minum Tirtamarta Kota Yogyakarta.

Adanya kerjasama antara PDAM Tirtamarta Kota Yogyakarta dengan SPAM Regional Kartamantul, guna untuk menyediakan air minum dan/atau air bersih pada masyarakat yogyakarta, adalah telah sesuai dengan Pasal 4 Ayat 2 PERDA No. 14 Tahun 2012 Tentang Perusahaan Daerah Air Minum Tirtamarta Kota Yogyakarta, Sehingga usaha yang dijalani PDAM Tirtamarta Kota Yogyakarta, pengelohan dan penyediaan 
air minum dan/atau air bersih adalah berpayung hukum dan/atau telah sesuai dengan dasar hukum yakni Pasal 4 PERDA No. 14 Tahun 2012 Tentang Perusahaan Daerah Air Minum Tirtamarta Kota Yogyakarta.

7. Sistem Pelaporan dan Pertanggun Jawaban PDAM Tirtamarta Kota Yogyakarta.

Sebagaimana telah diungkapkan diatas, PDAM Tirtamarta Kota Yogyakarta adalah perusahaan daerah dan/atau perusahaan milik daerah, yang dijadikan sebagai salah satu sumber pendapatan asli daerah (PAD) oleh pemerintah kota yogyakarta, dan oleh karena PDAM Tirtamarta adalah perusahaan daerah dan/atau milik daerah, maka pelaporan dan Pertanaggung jawbannya adalah kepada Walikota Yogyakarta. Bahwa untuk cara pelaporanya, PDAM Tirtamarta Kota Yogyakarta, setiap tahun melakukan 2 (dua) kali pelaporan dan pertanggung jawaban kepada Walikota yogyakarta, yakni per 3 (tiga bulan) yanag isi laporan dan pertanggung jawaban terkait dengan perhitungan hasil usaha dan kegiatan PDAM Tirtamarta Kota Yogyakarta dan laporan tahunan yang berhubungan dengan laporan perhitungan laba dan/atau rugi yang di alamai PDAM Tirtamarta Kota Yogyakarta dalam satu tahun berjalan (Mujiya, 12/12/2018).

Sehubungan dengan hal tersebut, pada dasarnya sistem dan/atau tata cara pelaporan dan pertanggung jawaban yang selama ini dilakukan oleh PDAM Tirtamarta Kota Yogyakarta, telah sesuai dengan Pasal 70 dan 71 Ayat 1 PERDA No. 14 Tahun 2012 Tentang Perusahaan Daerah Air Minum Tirtamarta Kota Yogyakarta. Dimana dalam pasal-pasal tersebut berbunyi sebagai berikut:

Pasal 70 PERDA No. 14 Tahun 2012 Tentang Perusahaan Daerah Air Minum Tirtamarta Kota Yogyakarta bahwa laporan berkala perhitungan hasil usaha dan kegiatan PDAM dikirim oleh Direksi kepada Walikota melalui Dewab Pengawas setiap 3 (tiga) bulan. Pasal 71 Ayat 1 PERDA No. 14 Tahun 2012 Tentang Perusahaan Daerah Air Minum Tirtamarta Kota Yogyakarta menyebutkan untuk tiap tahun buku Direksi menyampaikan Laporan Perhitngan Laba/Rugi dan Neraca kepada Walikota melalui Dewan Pengawas selambat-lambatnya 6 (enam) bulan setelah berakhir tahun buku dan setelah dilakukan Audit oleh Akuntan Negara atau Akuntan Publik. Selain telah sesuai dengan Pasal 70 dan 71 Ayat 1 PERDA 
No. 14 Tahun 2012 Tentang Perusahaan Daerah Air Minum Tirtamarta Kota Yogyakarta, pelaporan dan Pertanggung jawaban yang dilakukan oleh PDAM Tirtamarta Kota Yogyakarta, juga dipandang telah sesuai dengan Pasal 97 Ayat 1, 2 dan 3 PP No. 54 Tahun 2017 Tentang Badan Usaha Milik Daerah, dimana dalam pasal tersebut menyatakan:

Ayat 1: Laporan direksi BUMD terdiri dari laporan bulanan, laporan triwulan dan laporan tahunan.

Ayat 2: Laporan bulanan dan laporan triwulan sebagaimana dimaksud pada ayat 1 terdiri dari atas laporan kegiatan operasional dan laporan keuangan yang disampaikan kepada Dewan Pengawas atau Komisaris.

Ayat 3: Laporan tahunan sebagaimana dimaksud pada ayat (1) terdiri atas laporan keuangan yang telah diaudit dan laporan manajemen yang ditandatangani bersama Direksi dan Dewan Pengawas atau Komisaris

8. Penetapan dan Penggunaan Laba dan/atau Rugi Pada PDAM Tirtamarta Kota Yogyakarta.

PDAM Tirtamarta Kota Yogyakarta, sebagai salah satu perusahaan daerah kota yogyakarta, yang menjadi sumber pendapatan asli daerah (PAD), maka sudah tentu keuntungna dan/atau laba yang dihasilkan oleh PDAM Tirtamarta Kota Yogyakarta, akan dibagi pada pemirintah kota yogyakarta, selain itu juga akan digunakan untuk operasional guna menjalankan PDAM Tirtamarta Kota Yogyakarta, seperti penggunaan Jasa Produksi, dan penggunaan dana cadangan umum, dan selama ini pembagian keuntungan yang ada pada PDAM Tirtamarta Kota Yogyakarta dengan Pemerintah Kota Yogyakarta adalah dengan presentas 45\% (empat puluh lima perseratus) digunakan oleh PDAM Tirtamarta Kota yogyakarta, dengan komposisi penggunaan Jasa Produksi, penggunaan dana cadangan umum, dana pensiun dan sokongan, dan lain-lain. Sedangkan untuk pemerintah kota yogyakarta adalah 55\% (lima puluh lima perseratus) dari dana keuntungan dan/atau Laba yang diperoleh oleh PDAM Tirtamarta kota Yogyakarta (Mujiya, 12/12/2018).

Bahwa apa yang dilakukan dan/atau dikerjakan oleh PDAM Tirtamarta Kota Yogyakarta, terkait adanya pembagian keuntungan dan/laba kepada pemerintah kota yogyakarta dengan presentas $45 \%$ (empat puluh lima perseratus)untuk PDAM Tirtamarta Kota Yogyakarta 
dan 55\% (lima puluh lima perseratus) untuk pemerintah kota yogyakarta, adalah telah sesuai dan/atau telah diatur dalam Pasal 72 ayat 2 PERDA No. 14 Tahun 2012 Tentang Perusahaan Daerah Air Minum Tirtamarta Kota Yogyakarta, yang berbunyi sebagai berikut:

Pasal 72 Ayat 2: Penggunaan laba bersih setelah terlebih dahulu dikurangi dengan penyusutan, cadangan tujuan dan pengurangan lain yang wajar dalam PDAM ditetapkan sebagai berikut: (a) Bagian laba untuk daerah 55\% (lima puluh persen), (b) Cadangan Umum 10\% (sepuluh persen), (c) Sosial dan Pendidikan 5\% (lima persen), (d) Jasa Produksi 15\% (lima belas persen), (e) Dana Pensiun dan Sokongan 15\% (lima belas persen)

Selain diatur dalam Pasal Pasal 72 ayat 2 PERDA No. 14 Tahun 2012 Tentang Perusahaan Daerah Air Minum Tirtamarta Kota Yogyakarta, penggunaan keuntungan dan/atau laba suatu badan usaha milik daerah dan/atau perusahaan umum daerah juga diatur dalam Pasal 100 ayat 1 dan 2 PP No. 54 Tahun 2017 Tentang Badan Usaha Milik Daerah, yang berbunyi: penggunaan laba perusahaan umum daerah diatur dalam anggaran dasar. Pasal 100 ayat 2: penggunaan laba perusahaan umum daerah sebagaimana dimaksud pada ayat (1) digunakan untuk: (a) pmenuhan dana cadangan, (b) peningkatan kuantitas, kualitas, dan kontinuitas pelayanan umum, pelayanan dasar, dan usaha perintisan perusahaan umum daerah yang bersangkutan, (c) dividen yang menjadi hak daerah, (d) tantiem untuk anggota direksi dan dewan pengawas, (e) bonus untuk pegawai;dan/atau, (f) penggunaan laba lainnya sesuai dengan ketentuan peraturan perundang-undangan. Oleh karena itu, pembagian keuntungan dan/atau laba PDAM Tirtamarta Kota Yogyakarta, yang terbagi menjadi 2 (dua), antara PDAM Tirtamarta Kota Yogyakarta dan Pemerintah Kota Yogyakarta, adalah sudah sesuai dengan peraturan yang ada, yakni Pasal 72 ayat 2 PERDA No. 14 Tahun 2012 Tentang Perusahaan Daerah Air Minum Tirtamarta Kota Yogyakarta, dan Pasal 100 ayat 1 dan 2 PP No. 54 Tahun 2017 Tentang Badan Usaha Milik Daerah.

Selama PDAM Tirtamarta Kota Yogyakarta, didirikan dirasa belum pernah mengalami kerugian, namun jika kekurangan modal guna untuk pengembangan usahanya, PDAM Tirtamarta Kota Yogyakarta pernah mengalami, seperti pada tahun 2017, dimana PDAM Tirtamarta Kota Yogyakarta, telah meminta dana penyertaan pada pemerintah kota 
Yogyakarta, guna untuk pengembangan usahanya, yakni meminta dana penyertan untuk perbaikan pipa distribusi. Oleh karena PDAM Tirtamarta Kota yogyakarta, tidak pernah mengalami kerugian dalam menjalankan usahanya, sehingga peneliti tidak bisa memberikan analisa lebih jauh terkait hal tersebut, namun jika PDAM Tirtamarta Kota Yogyakarta melngalami kerugian dalam menjalankan usahanya, maka PDAM Tirtamarta Kota Yogyakarta dapat mengajukan likuidasi, hal sebagaimana diatur dalam Pasal 82 PERDA No. 14 Tahun 2012 Tentang Perusahaan Daerah Air Minum Tirtamarta Kota Yogyakarta, selain mengajukan likuidasi, PDAM Tirtamarta Kota Yogyakarta sebagai BUMD, jika terus-menurus dipandang kinerja semakin buruk dan mengalami kerugian, maka dapat dilakukan Restrukturisasi, hal ini sebagaimana di atur dalam Pasal 112 Ayat 3 PP No. 54 Tahun 2017 Tentang Badan Usaha Milik Daerah yang menyatakan bahwa restrukturasi dilakukan terhadap BUMD yang terus menerus mengalami kerugian dan kerugian tersebut mengancam kelangsungan usaha BUMD.

Selain hal tersebut diatas, dimana Badan Usaha Milik Daerah yang mengalami kerugian secara terus menerus, juga dapat dilakukan untuk pengambungan, peleburan, pengambilalihan dan pembubaran BUMD dan permohonan kepailitan, hal ini sebagaimana diatur dala Pasal 125 dan Pasal 127 ayat 3 PP No. 54 Tahun 2017 Tentang Badan Usaha Milik Daerah yang menyatakan: penggabungan, peleburan, pengambilalihan, dan pembubaran BUMD dilakukan berdasarkan hasil analisa investasi, penilaian tingkat kesehatan, dan hasil evaluasi BUMD. Pasal 127 Ayat 3 bahwa Direksi perusahaan persero daerah hanya dapat mengajukan permohonan kepada pengadilan agar perusahaan perseroan daerah dinyatakan pailit setelah memperoleh persetujuan dari kepala daerah dan DPRD, untuk selanjutnya ditetapkan di RUPS.

Setelah mengkaji dan mentelaah terkait Pengaturan dan Pengelolaan Sumber Daya Air di Perusahaan Daerah Air Minum (PDAM) Tirtamarta Kota Yogyakarta. Dengan beberapa item seperti, kepemilikan modal, bentuk perusahaan, pengangkatan direksi, bidang usaha, sistem pelaporan dan pertanggung jawaban serta penggunaan laba dan/atau rugi, semua yang dilakukan oleh PDAM Tirtamarta Kota Yogyakarta, mengacu dan/atau telah sesuai dengan peraturan yang ada, yakni PERDA No. 14 Tahun 2012 Tentang Perusahaan Daerah Air Minum Tirtamarta Kota 
Yogyakarta dan PP No. 54 Tahun 2017 Tentang Badan Usaha Milik Daerah. Hal ini dilakukan sebagai wujud bahwa PDAM Tirtamarta Kota Yogyakarta, sebagai badan usaha milik daerah dan/atau merupakan sumber Pendapatan Asli Daerah (PAD) adalah bagian yang tidak terpisahkan pada Pemrintah Daerah, dan untuk itu Pemerintah Daerah Kota Yogyakarta sebagai pemilik modal utama bagi PDAM Tirtamarta Kota Yogyakarta, harus ikut mengelola dan/atau menguasai dalam pengelolaan PDAM Tirtamarta, dan mengelola dan/atau menguasai dari Pemerintah Daerah kota yogyakarta tidak harus secara langsung ikut mengelola dan/atau menyelenggarakannya, namun bisa dalam bentuk pengawasan dan pembentukan peraturan-peraturan demi kelancaran perekonomian. Dan hal itulah yang saat ini dilakukan pemerintah kota yogyakarta, dengan dibentuknya PERDA No. 14 Tahun 2012 Tentang Perusahaan Daerah Air Minum Tirtamarta Kota Yogyakarta, Pemerintah Kota Yogyakarta telah ikut menguasai dan/atau mengelola PDAM Tirtamarta Kota Yogyakarta, sebagai badan usaha milik daerahnya dan merupakan sumber Pendapatan Asli Daerah (PAD) Pemerintah Kota Yogyakarta.

\section{SIMPULAN}

Mahkamah Konstitusi No. 85/PUU-XI/2013 Tentang Pembatalan UU No. 7 Tahun 2004 Tentang Sumber Daya Air, telah memberikan dampak yang signifikan bagi perkembangan sumber daya air, dimana sebelum ada Putusan Mahkamah Konstitusi No. 85/PUU-XI/2013 Tentang Pembatalan UU No. 7 Tahun 2004 Tentang Sumber Daya Air, pihak Swasta dapat dengan leluasa menguasai dan/atau mengelola sumber daya air, Namun setelah adanya Putusan Mahkamah Konstitusi No. 85/PUU-XI/2013 Tentang Pembatalan UU No. 7 Tahun 2004 Tentang Sumber Daya Air, konsep pengelolaan sumber daya air, berubah menjadi penguasaan pengelolaan sumber daya air dikelola oleh negara, dengan cara memberikan perioritas utama bagi Usaha Milik Negara atau Badan Usaha Milik Daerah untuk mengelola sumber daya air. dan konsep pengelolaan sumber daya air harus tetap mengacu pada Pasal 33 ayat (3) UUD 1945, dimana sumber daya air yang merupakan sumber-sumber penting bagi masyarakat harus dikuasia oleh negara dan dipergunakan untuk sebesar-besarnya kemakmuran rakyat, maka pengawasan dan pengendalian oleh negara atas air sifatnya mutlak. Hal ini sebagai 
perwujutan negara kesejahteraan yang harus mengutamakan kepentingan seluruh rakyat Indonesia dengan tugas dan fungsinya menyelenggarakan kepentingan umum. Pengaturan dan Pengelolaan Sumber Daya Air di Perusahaan Daerah Air Minum (PDAM) Tirtamarta Kota Yogyakarta. Yang dilakukan oleh PDAM Tirtamarta Kota Yogyakarta, telah sesuai dengan peraturan yang ada, yakni PERDA No. 14 Tahun 2012 Tentang Perusahaan Daerah Air Minum Tirtamarta Kota Yogyakarta dan PP No. 54 Tahun 2017 Tentang Badan Usaha Milik Daerah. Dan hal itu merupakan perwujutan pengelolaan dan/atau penguasaan Pemerintah Kota Yogyakarta, terhadap badan usaha milik daerahnya dan/atau Sumber Pendapatan Asli (Daerah) yang dimiliki oleh Pemerintah Kota Yogyakarta.

\section{DAFTAR RUJUKAN}

Abdulkadir Muhammad, 2010,"Hukum Perusahaan Indonesia",Bandung, Citra Aditya Bakti;

Aminuddin Ilmar "Hak Menguasai Negara Dalam Privatisasi BUMN" (Cet I), Jakarta, Kencana Prenada Media Group;

Bagir Manan, 1995,"Pertumbuhan dan Perkembangan Kosntitusi suatu Negara", Bandung, Mandar Maju;

Chabib Soleh dan Heru Rocmansjah, 2010, "Pengeloaan Keuangan dan Aset Daerah",Jakarta :Fokus Media;

Gunawan Widjaja, 2005,"Tanggung Jawab Direksi atas Kepailitan Perseroan", jakarta, Raja Grafindo Persada;

Hamid Chalid, 2009,"Hak-Hak Asasi Manusia Atas Air: Studi Tentang Hukum Air di Belanda, India dan Indonesa, Disertasi Doktor Ilmu Hukum FH UI, Jakrata: Program pasca Sarjana Strata;

I.C.Rai Widjaya, S.H.,M.A.2000," Penanaman Modal", Jakarta,PT Pradnya Paramita;

Indra Surya dan Ivan Yustiavandana, 2006, "Penerapan Good Corporate Governance Mengesampingkan Hak-hak Istimewa Demi Kelangsungan Usaha, Jakarta, Prenada Media Group;

IR. Purwadi,2002, "Penelitian tentang Strategi Pengembangan BUMD Non Perbankan dalam Meningkatkan Pendapatan Asli Daerah",Surabaya : Balitbang Daerah Provinsi Jawa Timur;

Mukti Fajar dan Yulianto Achmad, 2013, Dualisme Penelitian Hukum Normatif dan Empiris, Yogyakarta, Pustaka Pelajar;

Munir Fuady,2003,"Perseroan Terbatas Paradigma Baru", Bandung, Citra 
Aditya Bakti;

Rachmadi Usman, 2004,"Dimensi HukumPerusahaan Perseroan Terbatas", Bandung, PT. Alumni;

Richad Burton Simatupang, 2007," Aspek Hukum dala Bisnis, edisi Revisi, jakarta, Rineka Cipta;

Roni Hanittijo S, dan Rono Soemitro, 1984,"Masalah-masalah Sosiologi Hukum, Bandung, Sinar Baru;

Rudyanti Dorotea Tobing, 2015,"Aspek-aspek Hukum Bisnis Pengertian, Asas, Teori dan Praktik, Surabaya, Leks Bang Justitia;

Sunaryati Hartono, 1994, Penelitian Hukum di Indonesia Pada Akhir abad ke-20, Alumni, Bandung;

Prof. Dr. Zainal Asikin, S.H., SU \& Dr. L. Wira Pria Suhartana, S.H., M.H, 2016, “ Pengantar Hukum Perusahaan", jakarta, Pranadamedia Group.

Jurnal/Makalah/Website

Ambar Budhisulistyawati, Yudho Taruno Muryanto, Anjar Sri CN,2015,"Strategi Pengelolaan Badan Usaha Milik Daerah (BUMD) Persero Untuk Mewujudkan Prinsip Tata Kelola Perusahaan Yang Baik" (Jurnal Privat Law Vol.III No. 2 Juli-Desember 2015);

Dian Cahyaningrum, 2018,"Implikasi Bentuk Hukum BUMD Terhadap Pengelolaan BUMD", Jakarta, Pusat Penelitian Badan Keahlian DPR RI (Jurnal Negara Hukum: Vol. 9, No. 1 Juni 2018);

Hasbullah F. Sjawie, 2017,"Tanggung Jawab Direksi Perseroan Terbatas Atas Tindakan Ultra Vires, (Jurnal Hukum Prioris, Vol. 6 No. 1 Tahun 2017);

I Ketut Mardjana, 2002, "Corporate Governance dan Privatisasi" (Jurnal Reformasi Ekonomi, Vol 1, No. 2 Oktober-Desember 2002);

Irfan Nurahman, 2015, “ Implikasi Hukum Putusan Mahkamah Konstitusi

Tentang Pengujian Konstitusionalitas Undang-undang Sumber Daya Air, (Jurnal, Kajian Vol. 20 No. 2 Juni 2015);

Maya Sari, Abdul Rachmad Budiono, dan Hanif Nur Widhiyanti, 2017,"Perlindungan Hukum Bagi Pemegang Saham Minoritas yang tidak dilibatkan dalam proses Akuisisi", (Jurnal, Yuridika, Vol. 32, No. 3, September 2017);

Santi Puspitasari dan Utari Nindyaningrum, 2015," Implikasi Putusan Makhamah Konstitusi Nomor 85/PUU-XI/2013 Terhadap Sistem Penyediaan Air Minum.hlm. 46 (dalam Jurnal Penelitian Hukum 
Volume 2, Nomor 1, Maret 2015 Fakultas Hukum Universitas Gajah Mada);

Yordan Gunawan dan M Arizka Wahyu, 2016," Masa Depan hak Atas Air Pasca Putusan Mahkamah Konstitusi Nomor 85/PUU-XI/2013, hlm.115-116 (dalam Jurnal kajian Hukum, Vol. 1 No. 2 (2016) Fakultas Hukum Universitas Muhammadiyah Yogyakarta);

Yudho Taruno Muryanto dan Djuwitayastuti, 2014," Model Pengelolaan

Badan Usaha Milik Daerah (BUMD) dalam Rangkan Mewujudkan Good Corporate Governance" ( Jurnal, Yustisia Vol. 3 No. 1 Januari-April 2014)

--------“Alternatif Model Pengelolaan Badan Usaha Milik Daerah (BUMD) dalam Rangka Mewujudkan Good Corporate Governace", Jurnal, hlm. 4, Dikases 09 Mei 2017;

Putusan Mahkamah Konstitusi Nomor. 001-021-022/PUU-I/2003 Atas

Permohonan Pengujian Uundang-undang Nomor 20 Tahun 2002 Tentang Ketenagalistrikan;

Putusan Mahkamah Konstitusi No. 85/PUU-XI/2013 Tentang Pembatalan

UU No. 7 Tahun 2004 Tentang Sumber Daya Air;

http:/andichairulfurqan. Wordpress.com/tag/bumd/,Chairil Furkon "Badan

Usaha Milik daerah Sudah rawan" diakses 09 Agustus 2018.

\section{Undang-undang}

Undang-Undang Dasar 1945;

Undang-Undang No. 5 Tahun 1960 Tentang Peraturan Dasar Pokok Agraria;

Undang-Undang Nomor 5 Tahun 1962 tentang Perusahaan Daerah;

Undang-Undang Nomor 5 Tahun 1974 Tentang Pokok-Pokok Pemerintahan Di Daerah;

Undang-Undang Nomor 11 Tahun 1974 Tentang Pengairan;

Undang-Undang Nomor 5 Tahun 1979 Tentang Perusahaan Daerah;

Undang-Undang Nomor 7 Tahun 2004 Tentang Sumber Daya Air;

Undang-undang Nomor 23 Tahun 2014 Tentang Pemerintah Daerah ;

Undang-Undang Nomor 40 Tahun 2007 Tentang Perseroan;

Undang-Undang Nomor 25 Tahun 2007 Tentang Penanaman Modal;

PP No. 54 Tahun 2017 Tentang Badan Usaha Milik Daerah;

PERMENDAGRI No.3 Tahun 1990 Tentang Pengelolaan Barang Milik Daerah;

PERMENDAGRI No. 4 Tahun 1990 Tentang Kerjasama Antar Daerah; 
PERMENDAGRI No. 3 Tahun 1998 Tentang Bentuk Badan Usaha Milik Daerah;

PERPRES No. 38 Tahun 2015 Tentang Kerjasama Pemerintah Dengan Badan Usaha Dalam Penyediaan Infrastruktur;

Pemerintah Kota Yogyakarta Kepada Badan Usaha Milik Daerah;

PERDA Kota Yogyakarta No. 14 Tahun 2012 Tentang Perusahaan Daerah Air Minum Tirtanirmala Kota Yogyakarta. 